УДК $343.3 / 7$

DOI https://doi.org/10.32837/apdp.v0i88.3064

Ю. С. Мостович, Т. О. Мудряк

\title{
ОКРЕМІ АСПЕКТИ ВИЗНАЧЕННЯ ПРЕДМЕТА КРИМІНАЛЬНОГО ПРАВОПОРУШЕННЯ, ПЕРЕДБАЧЕНОГО СТАТТЕЮ 355 КРИМІНАЛЬНОГО КОДЕКСУ УКРАЇНИ
}

Для забезпечення швидкого реагування на порушення установлених цивільним законодавством правил реалізації особою права виконання цивільно-правових зобов'язань сформульована кримінально-правова норма про примушування до виконання чи невиконання цивільно-правових зобов'язань, що є заходом кримінально-правового характеру. Встановлення кримінальної відповідальності за примушування до виконання чи невиконання цивільно-правових зобов'язань полягає в забезпеченні захисту прав та законних інтересів громадян у разі укладення ними договорів, угод чи інших цивільно-правових зобов'язань.

У юридичній літературі зазначається, що предметом кримінального правопорушення, відповідальність за який передбачена ст. 355 Кримінального кодексу (далі КК), є саме цивільно-правове зобов'язання. Так, наприклад, Н. Ярмиш предметом кримінальногоправопорушенняпримушуваннядовиконаннячиневиконанняцивільно-правових зобов'язань називає цивільно-правові зобов'язання [1, с. 514]. В. Навроцький предметом даного кримінального правопорушення називає майно, право на майно, дії майнового характеру, особисті немайнові права, на одержання яких винний (чи той, в інтересах кого він діє) має право за договором, угодою чи іншим цивільно-правовим зобов' язанням, укладеними в установленому закономпорядку [2, с. 591].

За доктриною кримінального права предмет - це те, дією на що завдається шкоди об’єкту кримінального правопорушення, під час його вчинення. Тому предметом кримінального правопорушення, відповідальність за який передбачена ст. 355 КК України, є саме цивільно-правове зобов'язання.

До такої групи правовідносин, як зобов'язання, звертаються такі науковці, як: В. Парасюк, Н. Парасюк, К. Сінянський, Ж. Завальна й інші.

Кримінально-правові дослідження ознак примушування до виконання чи невиконання цивільно-правових зобов'язань проводили О. Гринишин, В. Навроцький, М. Арманов, О. Дудоров, А. Соловйова, М. Хавронюк та інші.

Науковці стверджують, що сфера, у якій застосовується термін «зобов'язання», натепер поступово розширюється, тому зобов'язання як цивільні правовідносини необхідно відрізняти від правовідносин, що регулюються іншими галузями права [3, с. 287]. Ст. 355 Кримінального кодексу України встановлює відповідальність за примушування до виконання чи невиконання лише цивільно-правових, а не будь-яких зобов'язань, обов'язок виконання яких встановлюється іншими нормами права. Так, примушування повнолітніх дітей, які згідно із законом зобов'язані утримувати непрацездатних батьків, які потребують матеріальної допомоги, і піклуватися про них, не утворює складу цього кримінального правопорушення,

(C) Ю. С. Мостович, Т. О. Мудряк, 2020 
оскільки згідно із чинним законодавством це зобов'язання не є цивільно-правовим. Примушування до виконання чи невиконання будь-яких інших (крім цивільно-правових) зобов'язань, якщо для цього є підстави, може кваліфікуватися як самоправство чи інше кримінальне правопорушення [4, с. 703].

Згідно з п. 15 постанови Пленуму Верховного Суду України «Про судову практику у справах про злочини проти власності» від 6 листопада 2009 р. № 10 (далі ППВСУ № 10), «>...> відповідальність за ст. 355 КК України може наставати лише тоді, коли особу примушують до виконання (невиконання) існуючого зобов'язання, що виникло на підставах, передбачених чинним законодавством. Отже, можна зробити простий висновок, що вимога виконати зобов'язання завжди має правомірний характер, оскільки грунтується на законному зобов'язанні» [5]. Зобов'язання як теоретико-правова категорія - це врегульовані нормами права суспільні відносини між правосуб'єктними суб’єктами, які виникають, змінюються і припиняються щодо як майнових, так і немайнових об'єктів, унаслідок чого в однієї зі сторін виникає обов'язок учинити певні дії чи утриматись від їх учинення, невиконання якого є підставою для застосування засобів юридичної відповідальності [6, с. 30]. Отже, зобов'язання можна вважати законним, якщо воно виникло на підставах, передбачених чинним законодавством. Підстави для виникнення цивільних прав і обов'язків визначаються ст. 11 Цивільного кодексу України (далі - ЦК України) та ст. 144 Господарського кодексу України, зокрема такими є:

- договори й інші правочини;

- створення та придбання майна;

- створення літературних, художніх творів, винаходів та інших результатів інтелектуальної, творчої діяльності;

- завдання майнової (матеріальної) та моральної шкоди іншій особі;

- порушення вимог закону під час здійснення господарської діяльності;

- збереження майна коштом іншої особи без достатніх підстав;

- акти цивільного законодавства;

- акти органів державної влади, органів влади Автономної Республіки Крим або органів місцевого самоврядування;

- рішення суду;

- настання або ненастання якоїсь події [7; 8].

Згідно з п. 4 ч. 2 ст. 11 Цивільного кодексу України, підставами для виникнення цивільних прав і обов'язків є також інші юридичні факти, саме тому перелік підстав для виникнення цивільних зобов’язань не є вичерпним [7].

Ж. Завальна у своїй праці зазначала, що зобов'язання, як і деякі інші явища правової дійсності, спрямовані на виникнення, зміну, припинення прав і обов'язків суб’єктів, які врегульовані нормами права, виникають з обставин дійсності, яким закон надає сили юридичних фактів. Закон не є єдиною підставою для виникнення зобов'язань, оскільки лише наявність життєвих обставин, які сприйняті та зафіксовані законодавцем як юридичний факт, та відповідна вказівка законодавця на це є підставою виникнення зобов'язання [9, с. 149]. Ще Г. Шершеневич зазначав, що для виникнення зобов'язання завжди потрібен юридичний факт, 3 настанням якого закон пов'язував би такий наслідок. I хоча прямим джерелом 
зобов'язання іноді визнається закон, проте основою зобов'язання може бути лише юридичний факт, а не закон, який становить загальну основу всіх правовідносин, а тому й не може бути названий джерелом зобов'язання [10, с. 351]. Отже, тільки закон, без наявності юридичного факту, не створює зобов'язання.

Окремі українські вчені дотримуються думки, що особа може примушуватися до виконання чи невиконання цивільно-правових зобов'язань не лише за дійсними, але й за недійсними чи відносно дійсними угодами [11, с. 594].

С. Яценко зазначає, що в разі вчинення кримінального правопорушення, передбаченого ст. 355 КК України, особа може примушуватись до виконання цивільно-правових зобов'язань не лише за дійсними, а й за недійсними чи відносно дійсними угодами. До недійсних угод закон відносить, зокрема, уявні, удавані, а також угоди, укладені: неповнолітнім, який не досяг віку п'ятнадцяти років; з метою, що суперечить інтересам держави і суспільства; громадянином, нездатним розуміти значення своїх дій; унаслідок помилки, обману, насильства, погрози, зловмисної угоди представника однісї сторони з іншої стороною або збігу тяжких обставин; юридичною особою в суперечності зі встановленою метою ї̈ діяльності. Недійсність цивільно-правової угоди не є перешкодою для кваліфікації діяння за ст. $355 \mathrm{KК}$ України, бо так само, як і дійсна, недійсна угода породжує певні цивільно-правові зобов’язання для однієї зі сторін. Наприклад, у разі визнання договору недійсним через його укладення внаслідок обману потерпілому повертається іншою стороною все отримане нею за договором, а якщо повернути отримане в натурі неможливо, то його вартість відшкодовується. Крім того, потерпілому відшкодовуються іншою стороною витрати, понесені ним, втрати або пошкодження майна [4, с. 703].

Інші вчені, зокрема В. Навроцький, уважають, що із законодавчого формулювання примушування до виконання чи невиконання цивільно-правових зобов'язань випливає те, що угода, укладена в установленому законом порядку, тобто $€$ дійсною, такою, що укладена дієздатною особою, без примусу, обману, не суперечить інтересам держави і суспільства, з дотриманням встановленої форми угоди тощо. На думку В. Навроцького, примушування до виконання недійсного правочину не може бути підставою для кваліфікації за ст. 355 КК України, оскільки в такому разі можна лише говорити про посягання на власність [12, с. 18].

М. Мельник підкреслює, що в разі вчинення злочину, передбаченого ст. $355 \mathrm{KK,}$ особа може примушуватися до виконання цивільно-правових зобов'язань не лише за дійсними, а й за недійсними чи відносно дійсними угодами [13, с. 818].

Недійсність правочину не є перешкодою для кваліфікації діяння за ст. 355, оскільки так само, як і дійсний, недійсний правочин породжує цивільно-правові зобов’язання для однієї зі сторін. Наприклад, у разі визнання правочину недійсним із причин укладення його внаслідок обману сторона, яка вдалася до обману, зобов'язана відшкодувати другій стороні збитки в подвійному розмірі та моральну шкоду, що завдані у зв'язку з учиненням цього правочину [13, с. 818].

О. Гринишин уважає, що в аспекті ст. 355 КК України не можна визнати таким, що виникло на законних підставах, зобов'язання з нікчемних правочинів. Зобов'язання ж з оспорюваних правочинів належить визнавати такими. Інакше кажучи, відповідальність за примушування до виконання цивільно-правових зобов'язань 
повинна наставати і тоді, коли потерпілого примушують до виконання оспорюваного правочину (але не нікчемного правочину). Виняток становить ситуація, коли судом винесено рішення про визнання оспорюваного правочину недійсним. У цьому разі зобов’язання вже не відповідає ознакам, зазначеним у ст. 355 КК України [14, с. 84].

Важливо правильно встановити момент учинення правочину. Зокрема, не є укладеними правочини, у яких відсутні встановлені законодавством умови, необхідні для їх укладення (відсутня згода за всіма суттєвими умовами договору; не передано майно, якщо відповідно до законодавства для вчинення правочину потрібна його передача тощо). Згідно зі ст. ст. 210 та 640 Цивільного кодексу України, не є вчиненим також правочин у разі нездійснення його державної реєстрації, якщо правочин підлягає такій реєстрації [15].

У постанові Пленуму Верховного Суду вказується, які цивільно-правові зобов'язання не підпадають під дію ст. 355 КК України: «вимога виконати (не виконати) зобов'язання, що виникло на підставах, не передбачених чинним законодавством, або неіснуюче зобов'язання, або зобов'язання з невизначеним предметом, а так само використання факту існуючого зобов'язання для заволодіння майном, правом на майно або для вчинення дій майнового характеру, які ним не передбачені, належить кваліфікувати як вимагання» [5].

Із цього можна зробити висновок, що зобов'язання в аспекті ст. 355 КК України повинно бути таким, що існує, умовою якого є виникнення з підстав, передбачених законодавством, а також на момент пред'явлення вимоги воно не має бути припиненим. Не можна кваліфікувати за ст. 355 КК України примушування до виконання зобов'язання, яке вже припинилось. Ще однією ознакою зобов'язання є наявність визначеного предмета, що, на думку О. Гринишина, охоплюється ознакою «існуючий». Він зазначає: «Якщо предмет договору невизначений, то зобов'язання є неіснуючим загалом» $[14$, с. 84$]$.

Отже, головний критерій правомірності кваліфікації за ст. 355 Кк України має виходити з визначених цивільним законодавством вимог щодо чинності правочину. Під час кваліфікації кримінального правопорушення за ст. 355 КК України не може враховуватися суб'єктивне ставлення суб'єкта кримінального правопорушення до законності своїх вимог щодо потерпілого. Важливо встановити, чи таке зобов’язання виникло на законних підставах і чи взагалі воно існує.

\section{Jimepamypa}

1. Кримінальне право України : Особлива частина : підручник / за ред. М. Бажанова, В. Сташиса, В. Тація. Київ ; Харків, 2001. 496 с.

2. Навроцький В. Кримінальне право України : Особлива частина : курс лекцій. Кииів : Т-во «Знання», $2000.771 \mathrm{c}$.

3. Парасюк В., Парасюк Н. Забезпечення порядку виконання зобов'язань : проблемні аспекти єдності цивільно-правового та кримінально-правового регулювання. Науковий вісник Львівського державного університету внутрішніх справ. 2016. С. 285-299.

4. Науково-практичний коментар до Кримінального кодексу України / відпов. ред. С. Яценко. Київ : А.С.К., 2005.848 с.

5. Про судову практику у справах про злочини проти власності : постанова Пленуму Верховного Суду України від 6 листопада 2009 р. № 10. URL: https://zakon.rada.gov.ua/laws/show/ v0010700-09\#Text (дата звернення: 12.10.2020). 
6. Сінянський К. Зобов'язання як теоретико-правова категорія. Науковий вісник Ужгородського національного університету. 2016. С. 25-31.

7. Цивільний кодекс України : Закон України від 16 січня 2003 р. № 435-IV / Верховна Рада України. URL: https://zakon.rada.gov.ua/laws/show/435-15\#top.

8. Господарський кодекс України : Закон України від 16 січня 2003 р. № 436-IV / Верховна Рада України. URL: https://zakon.rada.gov.ua/laws/show/436-15\#Text.

9. Завальна Ж. Щодо питання про юридичну природу зобов'язання. Часопис Київського університету права. 2012. С. 147-150.

10. Шершеневич Г. Курс гражданского права : автограф. Тула, 2001. 720 с.

11. Андрусів Г., Андрушко П., Беньківський В. Кримінальне право України : Загальна частина : підручник для студентів юридичних вузів і факультетів / за ред. П. Матишевського, П. Андрушка, С. Шапченка. Київ : Юрінком-Інтер, 1999. 512 с

12. Навроцький В. Злочини проти порядку управління : лекції для студентів юридичних факультетів. Львів, 1997. С. 40.

13. Науково-практичний коментар Кримінального кодексу України / за ред. М. Мельника, М. Хавронюка. 3-тє вид., переробл. та доповн. Київ : Атіка, 2003. 1056 с.

14. Гринишин О. Правомірність вимоги винного в аспекті «примушування до виконання цивільно-правових зобов'язань» (ст. 355 КК України). Підприємство, господарство і право. 2016. С. 82-86.

15. Про судову практику розгляду цивільних справ про визнання правочинів недійсними : постанова Пленуму Верховного Суду України від 6 листопада 2009 р. № 9. URL: http://zakon5.rada.gov.ua/ laws/ show/v0009700-09 (дата звернення: 12.10.2020).

\section{Анотація}

Мостович Ю. С., Мудряк Т. О. Окремі аспекти визначення предмета кримінального правопорушення, передбаченого статтею 355 Кримінального кодексу України. - Стаття.

У статті наведено всебічний аналіз цивільно-правових норм про зобов'язання та статті 355 Кримінального кодексу України, яка передбачає відповідальність за примушування до виконання чи невиконання цивільно-правових зобов'язань. Для забезпечення належного правозастосування системно проаналізовано норми цивільного і кримінального законодавства, що регламентують охорону встановленого порядку виконання цивільно-правових зобов'язань.

Проаналізована думка, що особа може примушуватися до виконання чи невиконання цивільно-правових зобов'язань не лише за дійсними, але й за недійсними чи відносно дійсними угодами. Висловлюється припущення, що недійсність цивільно-правової угоди не є перешкодою для кваліфікації діяння, бо так само, як і дійсна, недійсна угода породжує певні цивільно-правові зобов'язання для однієї зі сторін.

Розглядається також інша думка, що із законодавчого формулювання примушування до виконання чи невиконання цивільно-правових зобов'язань випливаєте, що угода укладена в установленому законом порядку, тобто є дійсною, такою, що укладена дієздатною особою, без примусу, обману, не суперечить інтересам держави і суспільства, з дотриманням встановленої форми угоди тощо.

Проаналізовано норми Цивільного та Господарського кодексів України, зазначено підстави для виникнення цивільних прав та обов'язків, перелік яких не $є$ вичерпним, адже закон не $є$ єдиною підставою для виникнення зобов'язань, оскільки наявність життевих обставин, які сприйняті та зафіксовані законодавцем як юридичний факт, та відповідна вказівка законодавця на це є підставою виникнення зобов'язання.

Зазначаються визначені цивільним законодавством вимоги щодо чинності правочину та види правочинів, які підпадають під предмет кримінального правопорушення за статтею 355 Кримінального кодексу України. Відзначено, що головним критерієм правомірності кваліфікації за статтею 355 Кримінального кодексу України є законність зобов'язання, тобто виникнення його на підставах, передбачених чинним законодавством. Важливо встановити, чи таке зобов'язання взагалі існує.

Ключові слова: зобов'язання, цивільно-правове зобов'язання, правочин, оспорюваний правочин, нікчемний правочин, примушування, захист, законність, правомірність. 


\section{Summary}

Mostovych Yu.S., Mudryak T.O. Some aspects of determining the subject of a criminal offense under Art. 355 of the Criminal Code of Ukraine. - Article.

The article provides a comprehensive analysis of civil law obligations and Article 355 of the Criminal Code of Ukraine, which provides for liability for coercion or non-performance of civil obligations. To ensure proper law enforcement, the norms of civil and criminal legislation governing the protection of the established procedure for the performance of civil law obligations have been systematically analyzed.

The point of view that a person can be forced to fulfill or fail to fulfill civil law obligations not only under valid, but also under invalid or relatively valid agreements is analyzed. It is suggested that the invalidity of a civil agreement is not an obstacle to the qualification of the act, because as well as a valid, invalid agreement gives rise to certain civil obligations for one of the parties.

Another point of view is also considered, that from the legislative formulation of coercion to fulfill or non-fulfillment of civil law obligations it follows that the agreement is concluded in the order established by the law, i.e. is valid, concluded by the capable person, without coercion, deception, does not contradict interests. the state and society, in compliance with the established form of the agreement, etc.

The norms of the Civil and Commercial Codes of Ukraine are analyzed, the grounds for civil rights and obligations are indicated, the list of which is not exhaustive, because the law is not the only basis for obligations, as the existence of life circumstances perceived and recorded by the legislator as a legal fact and the relevant instruction of the legislator to this is the basis for the obligation.

The requirements determined by the civil legislation concerning the validity of the transaction and the types of transactions that fall under the subject of a criminal offense under Article 355 of the Criminal code of Ukraine. It is noted that the main criterion for the legality of qualification under Article 355 of the Criminal code of Ukraine there is a legality of the obligation, i.e. its occurrence on the bases provided by the current legislation. It is important to establish whether such an obligation exists at all.

Key words: obligation, civil obligation, transaction, disputed transaction, void transaction, coercion, protection, legality, legitimateness. 